\title{
Heidegger's embodied others: on critiques of the body and 'intersubjectivity' in Being and Time
}

\author{
Meindert E. Peters ${ }^{1}$ (D)
}

Published online: 21 June 2018

(C) The Author(s) 2018

\begin{abstract}
In this article, I respond to important questions raised by Gallagher and Jacobson (2012) in the field of cognitive science about face-to-face interactions in Heidegger's account of 'intersubjectivity' in Being and Time. They have criticized his account for a lack of attention to primary intersubjectivity, or immediate, face-to-face interactions; he favours, they argue, embodied interactions via objects. I argue that the same assumption underlies their argument as did earlier critiques of a lack of an account of the body in Heidegger (e.g. Sartre 1989; Krell 1992); namely that because the body is not explicitly discussed in Being and Time, embodiment, rather than stressing the immediacy of experience, is insufficiently acknowledged in his emphasis on 'being-inthe-world'. Through placing Gallagher and Jacobson's accounts of intersubjectivity and the body alongside Heidegger's accounts of Mitsein and Leib, this article shows Heidegger's radical position on the body as immersed in a holistic environment, and its reverberations on his account of intersubjectivity. I argue that Dasein's embodied engagement in the world is always one of immediacy and that the body of the other is perceived as 'tied into' its context, as well. In so doing, I offer an Heideggerian account of ecstatic involvement which moves away from the distinction between primary and secondary intersubjectivity toward an immediate engagement with objects and people always already 'tied into' a context; an account that, through the concept of Fürsorge, includes shifts of attention between objects and people that allow for the ethical distinctions Gallagher and Jacobson are looking for.
\end{abstract}

Keywords Martin Heidegger - Intersubjectivity · Embodiment · Interaction · Ecstatic involvement $\cdot$ Being-with

Meindert E. Peters

meindert.peters@new.ox.ac.uk

1 New College, University of Oxford, Holywell Street, Oxford OX1 3BN, UK 
In The Basic Problems of Phenomenology Martin Heidegger writes: '[Dasein] finds itself primarily and constantly in things because, tending them, distressed by them, it always in some way or other rests in things' (1988, p. 159). In the fundamental ontology as proposed in his Being and Time (1927) Heidegger began painting this picture of human existence (Dasein) in which we are always already in the world, submerged in our environment. Rather than the Cartesian subject who takes a step back from the physical world, contemplating the world from a distance because thought is supposedly the only thing we can be sure of, in Heidegger we find ourselves already moving through the world, handling objects, and being amongst other people. Yet, even though Heidegger's account of Dasein shows it as always already physically engaged with the world, Being and Time has often been criticized for not containing an explicit discussion of the body. For example, De Waelhens, in his introduction to The Structure of Behaviour by Merleau-Ponty, writes that Heidegger in Being and Time only devotes ten lines to the problem of the body (1965, p. xviii). In a series of lectures published as the Zollikon Seminars in 1987, Medard Boss confronted Heidegger with a similar critique by Jean-Paul Sartre: '[Sartre] wondered why you only wrote six lines about the body in the whole of Being and Time' (Heidegger 2001, p. 231). Heidegger reacted to this criticism by stating that his idea of the body should not be seen in the light of a dichotomy between body and mind and that he was not talking about an object called body (Körper) but rather a living body open to the world (Leib) (2001, p. 89-90). ${ }^{1}$ His reluctance to provide a direct treatment of the body in Being and Time, it seems, derived from his fear of turning the body into an object of contemplation, transforming it into a Körper, and thus once again setting up the Cartesian dichotomy. Instead he chose to emphasize the world in which and with which the body as Leib is always already engaged. ${ }^{2}$

A similar interpretation of the absence of the body in Being and Time underlies Gallagher and Jacobson's recent critique of Heidegger's treatment of intersubjectivity in the context of exploring the relationship of Heidegger's work to advances in the cognitive sciences (2012). For Heidegger, being-in-the-world is both being with other people as well as being with and handling objects. We are not only always already in the world with other things, we also already encounter other people in relation to these objects. Through this structure we are part of an intersubjective relation with others that he calls 'being-with' (2010, p. 111ff). Through being-with we have an everyday familiarity with other people in the shared world of objects and people we encounter. Gallagher and Jacobson criticize Heidegger's treatment of intersubjectivity for overlooking what Trevarthen first defined as primary intersubjectivity, i.e. direct, face-to-face relations (Trevarthen 1979), ${ }^{3}$ which has been a central concept in a wide

\footnotetext{
${ }^{1}$ Franz Mayr and Richards Askay in their translation of the Zollikoner Seminare translate Körper and Leib as 'corporeal thing' and 'body' respectively. Although this translation emphasizes the connection between the German 'Körper' and the English 'corporeal' it does not emphasize the importance of Heidegger's use of 'Leib' and the verb 'leiben' which shares its etymology with 'leben' 'to live'. In order to stress Heidegger's move away from any understanding of the body as a lifeless object, a connection which is still there in 'body' in its sense of a corpse, in this article 'Leib' will either be referred to as 'living body' or left untranslated. All quotations of translations of the Zollikoner Seminare are altered to keep the original 'Leib'.

${ }^{2}$ That said, in the Zollikon Seminars Heidegger does admit to not having had an adequate understanding of the body yet at the time of writing Being and Time to say more about the subject. Heidegger (2001), p. 231.

${ }^{3}$ Although Trevarthen coined the term 'primary intersubjectivity' Bateson (1975) already showed the presence of it in the infant and their mother. For more on primary intersubjectivity in the newborn see, for example, Meltzoff and Moore (1977), Trevarthen (1980), Legerstee (1991), and Meltzoff and Brooks (2001).
} 
range of research in the cognitive sciences (e.g Gallagher 2001, 2005; Ratcliffe 2007; Butterworth 2004; De Jaegher and Di Paolo 2007; Colombetti 2014). According to Gallagher and Jacobson, Heidegger's account is lacking because it only discusses indirect relations between people: relations that move from person to object to person.

This article argues that Gallagher and Jacobson's criticism, although opening up important questions about the place of immediate, emotionally rich, face-to-face encounters in Being and Time, shares the same assumption that drove the critiques of Merleau-Ponty and Sartre: that because the body is not explicitly discussed as a Körper, that embodiment must therefore be insufficiently acknowledged in Heidegger's emphasis on being-in-the-world, rather than stressing the immediacy of experience. Through placing Gallagher and Jacobson's account of embodied practice (section 2 of this article) and intersubjectivity (sect. 4) alongside Heidegger's corresponding notions of Leib (sect. 1) and being-with (sect. 3), this article will try to develop a better understanding of these concepts central to Being and Time and emphasize, in Heidegger, the extent of the body's immersion in the world. In so doing, I attempt to show that Heidegger's account of intersubjectivity is one of immediacy, thereby trying to defend Heidegger against Gallagher and Jacobson's claim that he does not have an account of the kind of immediate, face-to-face relation they call primary intersubjectivity. This article, thereby, does not only hope to show that an engagement with the fields of the cognitive sciences, developmental psychology and the philosophy of mind can bring new insights into studies of Heidegger's philosophy; it also hopes to offer an account of how Heidegger's insights into intersubjectivity and the body can contribute to inquiries into the so-called 'Problem of Other Minds' within these fields.

\section{Heidegger's Leib as being-in-the-world}

In Being and Time Heidegger argues that Dasein is always already in the world and that we are, thus, always already surrounded by objects. At the moment when we become conscious of the world, we already stand in relation to these objects. We are already familiar with them, we are already using them as tools. Rather than contemplating these objects from a distance, we already have knowledge of them in their usefulness, or what Heidegger calls their Zuhandenheit (readiness-to-hand) (2010, p. 67ff). A fork, for example, is always already seen as a thing to eat with. I can, of course, see a fork as a piece of metal of certain measurements, I can rationalize it - this is what Heidegger states that science does - but that actually takes me a step back from how this thing has meaning to me in my everyday existence. Even if I have never seen a fork before, I will approach it as lacking a function, as having a 'disruption of reference' [Störung der Verweisung], or approach it as to what I think its use may be (2010, p. 74). ${ }^{4}$ This is illuminatingly shown in the Walt Disney film The Little Mermaid (2013). When Ariel comes across a fork for the first time in her life, she approaches it as the tool she thinks

\footnotetext{
${ }^{4}$ According to Heidegger, when objects are not obviously Zuhanden because either 1) they are unuseful to us or we do not know their use (Aufsässigkeit), 2) they are broken (Auffälligkeit) or because 3) another tool to use it with is failing (Aufdringlichkeit), they show themselves in their Vorhandenheit (objective presence). Yet, the usual Zuhandenheit only becomes more apparent in this Vorhandenheit. He states: '[w] hat is at hand is not thereby observed and stared at simply as something present. The character of objective presence making itself known is still bound to the handiness of useful things' (2010, p. 73).
} 
it most resembles: a comb. Particularly in these moments where we do not know the function of tools or where they simply do not function as they should, the extent to which we count on the world in its Zuhandenheit becomes apparent. The world according to Heidegger thus has meaning to us in its use, knowledge we have, first and foremost, through our physical using: 'the less we just stare at the thing called hammer, the more we take hold of it and use it, the more original our relation to it becomes and the more undisguisedly it is encountered as what it is, as a useful thing' (2010, p. 69).

French phenomenologists and psychologists such as Sartre and Merleau-Ponty have criticized Heidegger, implicitly and explicitly, for his lack of discussion of how the body functions in this being-in-the-world (Sartre 1989; Merleau-Ponty 1965; De Waelhens 1965). Contemporary thinkers have uttered similar reservations in their discussion of Being and Time. Krell, for example, asks: '[d]id Heidegger simply fail to see the arm of the everyday body rising in order to hammer the shingles on the roof?' (1992, p. 52). ${ }^{5}$ However, as Cerbone (2000) and Overgaard (2004) amongst others have argued, such a discussion of the body's functioning as proposed by Krell removes this body from the world it is engaged in, by putting attention to the arm rather than the hammering. ${ }^{6}$ It turns the arm into an objective thing-what Heidegger calls Vorhandenheit [objective presence] - or at least into the object of our objectifying thought, and therefore delineates the body from consciousness, bringing us back to the Cartesian dichotomy between body and mind that Heidegger is trying to overcome. In the Zollikon Seminars, held from 1959 to 1969, Heidegger also makes this point and his explanations help illuminate his understanding of the body as being-in-the-world as earlier proposed in Being and Time. In response to the criticism leveled by Sartre and other French thinkers, he states: '[a]s for the French authors, I am always disturbed by [their] misinterpretation of being-in-theworld; it is conceived either as objective presence or as the intentionality of subjective consciousness' (Heidegger 2001, p. 272). ${ }^{7}$ Heidegger's idea of beingin-the-world overcomes this separation between body and mind, as he states in the Zollikon Seminars, by foregrounding Leib over Körper, where the first is a living body and the second mere object. ${ }^{8}$ Leib for him denotes the way in which the body is engaged with the world: '... my sitting on the chair here, is essentially always already a being-there at something. My being-here, for instance, means: to see and hear you there' (2001, p. 97). Thus, taking Leib to mean being-in-theworld, Heidegger in Being and Time does put forward his ideas on the body by describing the ways in which we are always already in the world and engaged with it, by describing the body's interactions rather than the body itself. Leiben [bodying-forth] for Heidegger just is being-in-the-world and vice versa. ${ }^{9}$ More

\footnotetext{
5 See also Didier Franck's 'Being and the Living' (1991).

${ }^{6}$ See also Aho (2009) and Levin (1999).

${ }^{7}$ In order to ensure continuity between Stambaugh's translation of Sein und Zeit and Mayr and Askay's translation of the Zollikoner Seminare, this quotation has been altered in its translation of 'Vorhandenheit' from 'being present-at-hand' to Stambaugh's 'objective presence.'

${ }^{8}$ Heidegger points out that the French language only has a word for Körper (le corps) but not Leib. Heidegger, Zollikon Seminars (2001), p. 89.

9 Although 'leiben' is usually translated as 'bodying-forth,' this translation still seems to underestimate the extent to which leiben is lived experience away from the body as thing. In this article, 'leiben' will, therefore, simply be left untranslated, and all quotations of translations are altered accordingly.
} 
focus on the body itself would only remove the body from the very situatedness Heidegger wants to put it in, strip it from its context, and, thus, take a step back from the fundamental ontology Heidegger is interested in. In other words, the Cartesian dichotomy that Heidegger is overcoming is not only that between body and mind, but also that between the (embodied) subject and their environment (see also Wheeler 2005, p. 22-23).

\section{Physical being: Gallagher's 'body schema' versus Da-sein}

In How the Body Shapes the Mind (2005), Gallagher proposes a similar understanding of the body as Leib. Combining neuro-scientific research with phenomenologyespecially that of Merleau-Ponty - he forwards an excellent new approach to thinking about the body-mind relation within the neurosciences. As in a variety of works ranging from Head and Holmes (1911-12) to Merleau-Ponty (1965), he makes a similar distinction to Heidegger's Körper and Leib in the distinction between 'body image' and 'body schema' (Gallagher 2005, p. 17ff). ${ }^{1011}$ The difference between 'body image' and 'body schema' is the consciousness we have of the body. He states that when the body appears in consciousness it is clearly delineated from its environment. The 'body image' is a system of such conscious images of the body that treat it as an object (Gallagher 2005, p. 37). Yet it often focuses on one part of the body such as a failing knee. Similar to the way in which in Heidegger a tool only becomes apparent to us in its Zuhandenheit when it fails in performing its function, the knee only becomes an image to the mind when it fails to do its job. These borders between body and environment are obscured, however, when one is immersed in experience. 'The body schema functions in an integrated way with its environment, even to the extent that it frequently incorporates into itself certain objects' $(2005$, p. 37). Thus, the fork or the hammer that we handle can become part of the 'body schema.' The constitution of this schema also involves what Gallagher calls a 'prenoetic performance' of the body: 'a prenoetic performance is one that helps to structure consciousness, but does not explicitly show itself in the contents of consciousness' (2005, p. 32). Much like Heidegger's idea of leiben, then, such a prenoetic performance gains knowledge of the world through embodied practice ( 2005 , p. 36-7). ${ }^{12}$ Thus, although Gallagher spends only a couple of lines on Heidegger in his book, highlighting Merleau-Ponty's philosophy instead, his distinction between 'body image' and 'body schema' is strikingly similar to Heidegger's distinction between Körper and Leib. Both make a distinction in order to emphasize the body in its active and practical position in the world through which it gains knowledge.

\footnotetext{
${ }^{10}$ See Tiemersma's Body Schema and Body Image: An Interdisciplinary and Philosophical Study (1989) for a comprehensive overview of the literature.

${ }^{11}$ In the first chapter of How the Body Shapes the Mind Gallagher describes the 'terminological and conceptual confusions' between the two terms. Merleau-Ponty's 'schéma corporel' for example was rendered into 'body image' in Fischer's English translation of the work (Gallagher 2005, p. 17-39).

${ }^{12}$ Gallagher interestingly shows how 'body image' and 'body schema' can feed into one another, blurring the clear distinction between the two, particularly on a behavioral level. As an example he mentions the way in which dancers and athletes train deliberate movements until they become part of the 'body schema.'
} 
However, although this distinction is apparent in both Heidegger and Gallagher, Heidegger's idea of Leib goes a step further than Gallagher's idea of the 'body schema'. Whereas 'body schema' is the way in which the body is situated in the world, Heidegger's Leib does not just overcome the body-mind dichotomy by putting forward an idea of embodied practice, but it also overcomes the boundaries of that body by placing us elsewhere. The $d a$ of Heidegger's famous Dasein does not refer merely to a situatedness in our body in the world, but to being 'there' rather than being, firmly positioned, here. Hence, he states in the Zollikon Seminars: '[t]he limit of Leiben (Leib is only as it leibs: "Leib") is the horizon of being within which I sojourn [aufhalten]. Therefore, the limit of my Leiben changes constantly through the change in the reach of my sojourn.' (2001, p. 87). ${ }^{13}$ In Da-sein my Leib is oriented toward its world, and open to it. ${ }^{14}$ So rather than contemplating the way in which my hand works, which would be to see it as Vorhanden, rather than describing the experience of how my hand is hammering, as an intentionality of my consciousness, what Heidegger is trying to show is that when I am hammering a nail into the wall my preoccupation is with the hammer, the nail, and the wall which constitute the world in front of me. The major difference between Gallagher's 'body schema' and Heidegger's Leib is that whereas the 'body schema' may take a tool into its schema, still preoccupied with its own 'schema', the openness and outward orientation of Da-sein toward the world constitutes a Leiben that is also always already elsewhere. That is not to say that a similar kind of absorption of the body in the world that we find in Heidegger is not also found in Gallagher - see for example his phenomenological description of grabbing a book to read out a passage in How the Body Shapes the Mind (2005; p. 32) — but to show that where Gallagher's 'body schema' can be absorbed in the world, Heidegger's Leib exists only insofar as it is absorbed in the world.

\section{World as shaped by the Dasein of others: 'intersubjectivity' in Heidegger}

This difference in Heidegger's Leib and Gallagher's 'body schema' carries through in their understanding of intersubjectivity, or what Heidegger calls being-with [Mitsein] and leads, so I want to argue, Gallagher and Jacobson to criticize Heidegger's account of intersubjectivity. In Heidegger's account we, in our engagement with objects, in our everyday familiarity with them, also stand in relation to, and come across, other people:

The field, for example, along which we walk "outside" shows itself as belonging to such and such a person who keeps it in good order, the book which we use is bought at such and such a place, given by such and such a person, and so on. The

\footnotetext{
${ }^{13}$ Heidegger, Zollikon Seminars (2001), p. 87. 'Grenze des Leibens (der Leib ist nur insofern er leibt: Leib) ist der Seins-horizont, in dem ich mich aufhalte. Deshalb wandelt sich die Grenze des Leibens ständig durch die Wandlung der Reichweite meines Aufenthaltes' (Heidegger 1987, p. 113).

${ }^{14}$ Heidegger states: 'Nevertheless, from the Da-seinanalytic perspective, it remains decisive that in all experience of the bodily [des Leiblichen] one must always start with the basic constitution of human existing, that is, from being-human as Da-sein - as existing, in the transitive sense, of a domain of standing-opentoward-the-world; therefore, from this standing-open, in the light of this standing-open, the significant features of what is encountered address the human being' (Heidegger 2001, p. 231).
} 
boat anchored at the shore refers in its being-in-itself to an acquaintance who undertakes his voyages with it, but even as a "boat which is unknown to us," it still points to others. $(2010$, p. 115)

In my practical being in the world with objects I am thus also already surrounded by others. It might seem strange for Heidegger to start his discussion of other people with objects around us, but it points to Heidegger's belief that others cannot be understood away from the (shared) world and vice versa.

This statement needs unpacking. Just as Heidegger believes we engage with objects pragmatically, see them in their usefulness, so we engage with other people pragmatically, too. Like with tools, we always already know how to engage with other people, and do so. This fundamental way of always already being among others is what Heidegger calls being-with [Mitsein] $(2010, \S 26)$. We might take a step back and think about what other people are thinking, but this is generally not how we deal with other people. 'Most of the time,' so Dreyfus writes, 'Heidegger points out, we just work with and deal with others skillfully without having any beliefs about them or their beliefs at all' (1997, p. 148). At the same time, and this is why objects are relevant to how we come across others, we see others in their practical, meaningful engagement in the world too: "when others become, so to speak, thematic in their Dasein, they are not encountered as objectively present thing-persons, rather we meet them "at work", that is, primarily in their being-in-the-world.' (2010, p. 117). Other people are thus part and parcel of our meaningful environments. Their meaningful activities are part of the environments that our living bodies are immersed in: 'the "world" is also Dasein' (Heidegger 2010, p. 115).

But other people are also shaped by the world. While in Being and Time our encounter with others stays on a certain level of abstraction, in the Zollikon Seminars, Heidegger pays more attention to the fact that we encounter other people as living bodies and shows them as entangled in our meaningful, shared world. He argues against the understanding of another person's movement as expression [Ausdruck]; instead reading movement as gesture [Gebärde] (2001, 88ff). Movement always stands in relation to a meaningful environment, he argues, and therefore is not mere movement, or an expression of an inner thought or feeling, but rather a gesture:

Within philosophy we must not limit the word "gesture" merely to "expression." Instead, we must characterize all comportment of the human being as being-inthe-world, determined by the Leiben of the body. Each movement of my body as a "gesture" and, therefore, as such and such a comportment does not simply enter into an indifferent space. Rather, comportment is always already in a certain region [Gegend] which is open through the thing to which I am in a relationship, for instance, when I take something into my hand (2001, p. 90-91).

And when applied more directly to intersubjective relations:

But what lies in the phenomenon of blushing itself? It too is [Es ist auch] a gesture insofar as the one who blushes is related to his fellow human beings. With this you see how bodiliness has a peculiar "ecstatic" meaning. I emphasize this to such a degree in order to get you away from the misinterpretation of "expression" 
[von der Ausdruck-Mißdeutung]! French psychologists also misinterpret everything as an expression of something interior instead of seeing the phenomena of the body in the context of which men are in relationship to each other [mitmenschlichen Bezogenheit] (2010, p. 91, German additions mine). ${ }^{15}$

Every movement of the human body for Heidegger is gesturing toward something, and should thus be seen as a gesture. He moves away from an idea of expression, of someone having a thought and then expressing that in her movement, toward the movement not gesturing backward, inside, but forward in regard to its meaning. In other words, we should not look at the movement of someone as something that comes from inside but indeed something that is always already ecstatic, connecting and reacting to a meaningful outside world. Just as we ourselves are $d a$, then, preoccupied with the world in our Leiben, so others are always encountered as entangled in the world, as well. They, too, are animated by the world, and we see them as such. Hence, what we are engaging with in others is what Dreyfus calls their 'directed, significant, concernful comportment' (1997, p. 147), a totality of movements which points away from their bodies toward the things in the world they are preoccupied with.

But while we are always already engaging with the way in which others are meaningfully engaging with the world, grow up doing so, we also always already engage with the world as others engage with it, according to Heidegger. The way in which I am made to engage with this world is just an image of how someone else is; while riding a bus, Heidegger says, anyone is like anyone (2010, p. 123). How I eat with a fork is just how one eats with a fork. Through this shared world, being amongst objects referring to other people, we are shaped by the cultural and historical framework in place. This whole framework is what Heidegger calls das Man. ${ }^{16}$ Aho writes, referring to das Man as "Anyone": "The anonymous "They" or "Anyone" refers to a totality of interconnected relations; customs, occupations, practices and cultural institutions as embodied in gestures, artifacts, monuments, and so forth. This totality of relations gives meaning to beings' $(2009$, p. 20$)$. So not only am I always already in the world with objects, and with others using objects, I am also already with others using these objects as one uses them. Their gestures are my gestures; we have always already learned to be a body from others. Significantly, then, it is exactly because I am always already using objects as one uses them, because I am part of das Man, that I also

\footnotetext{
${ }^{15}$ While Mayr and Askay have done a great job at the difficult task of translating Heidegger, I have added some of the original German as I think the translation at times needs clarification, or the addition of the ambiguity from the original. In the second quoted line, for example, the English reads 'It too' but the German 'Es ist auch' also leaves open the possibility that Heidegger means to say that 'It is also a gesture'. The former makes more sense to how I understand Heidegger to think about blushing as a gesture, but the ambiguity of the original should be noted. 'Misinterpretation of "expression"' for 'Ausdruck-Mißdeutung' seems to say that the word 'expression' is misinterpreted, while I think Heidegger means that movements are misinterpreted as expression. 'Of which men are in relationship to each other' is a rather clunky translation of 'mitmenschlichen Bezogenheit', where something like 'interhuman relation' would have sufficed.

${ }^{16}$ Dreyfus famously translates 'das Man' as 'the one' rather than the usual 'the They' which he finds misleading 'since it suggests that $I$ am distinguished from them, whereas Heidegger's whole point is that the equipment and roles of society are defined by norms that apply to anyone. But even translating das Man by "we" or "anyone" does not capture the normative character of the expression. We or Anyone might try to cheat the Internal Revenue Service, but still one pay's one's taxes' (Dreyfus 1997, p. 151-2).
} 
already understand the actions, and thoughts in the actions, of other people. Their gestures are my gestures; our embodied existence is a shared one. It is because our meaningful world, and our gestures toward it, are shared that I can 'count[] on' (Heidegger 2010, p. 122) people doing things a certain way in a certain situation. ${ }^{17}$ It is only because of this shared understanding of the world that I even can be surprised by other people's actions, and that I might feel the need to take a step back from my everyday interaction to contemplate the other person's beliefs. Hence, we always already understand the other, because like us, they are animated by a shared world, indeed they derive their meaning from their engagement in it. All in all, in Heidegger, other people are far from the 'ineffable and radical exteriority' that they are for someone like Lévinas (Zahavi 2001, p. 159). Heidegger emphasizes that other people are those ontologically closest to us: '[o]thers are [...] those from whom one mostly does not distinguish oneself’ (2010, p. 115).

\section{4 'Intersubjectivity' in Gallagher and Jacobson: positioned rather than 'there'}

At first view Gallagher's understanding of intersubjectivity, as shown in a number of his works, is similar to how Heidegger believes we are being-with and part of das Man (Gallagher 2001, 2004, 2008; Gallagher and Jacobson 2012; Gallagher and Zahavi 2008). Whereas the traditional theories of mind, 'theory theory' and 'simulation theory,' state that we infer another person's mental state from the other person's behaviour, turning them into theoretical problems, the 'interaction theory' Gallagher proposes argues that our 'immediate, non-mentalistic mode of interaction' with the world already gives us a sense of how other people think (Gallagher and Jacobson 2012, p. 217-9). ${ }^{18}$ Gallagher and Jacobson state:

Thus, what we call the mind of the other person is not something that is entirely hidden away and inaccessible. Rather, in our encounters with others we not only have perceptual access to another person's intentions, because their intentions are explicit in their embodied actions and expressive behaviors, but also their actions

\footnotetext{
${ }^{17}$ While Heidegger separates his treatment of being-with and das Man and never explicitly addresses their connection, I take them to be two sides of the same coin, connoting different aspects of the same understanding of intersubjectivity whereby we are always already with other people doing things with them, alongside them, against them, as one does them. But where being-with is emphasizing the way in which we engage with others, Heidegger's treatment of das Man focuses on the normative structures guiding our behavior, thereby doing away with a notion of a separate self: "Initially, "I" "am" not in the sense of my own self, but I am the others in the mode of the they' (2010, p. 125).

It should be noted that, like Carman (1994) and Dreyfus (1995), I take Heidegger to say that das Man is a basic constitution of Dasein, and that any authenticity supervenes on it. Olafson (1987, 1994), in contrast, understands das Man in psychological terms, as something to be overcome through authenticity which is basic. But this, as Olafson himself also recognizes (but as a problem in Heidegger), takes away the shared world from being-with and opens up a need for 'an agreement among human beings' (Olafson 1987, p. 242) which in Carman and Dreyfus' accounts is taken up by das Man.

${ }^{18}$ In Gallagher and Jacobson's understanding, both in theory theory (TT) as well as simulation theory (ST) we attempt to understand others by 'attempting to infer or "mindread" the other's mental processes' (217). TT claims we do so through constructing a theory, thus, applying folk psychology, whereas ST states we do not need such folk psychology as we have our own mind as a model.
} 
resonate in our own motor systems. Other persons elicit our enactive response; they have an effect on us that is not reducible to a subjective simulation or an empathic response to the other's behavior but attunes our system to further possible interaction. (2012, p. 220)

Just as in Being and Time, they propose a physical being with one another that gives us a non-mentalistic understanding of each other. Their analysis of intersubjectivity differs, however, from Heidegger's in that they make a distinction between primary and secondary intersubjectivity (2012, p. $119 \mathrm{ff}){ }^{19}$ They adopt these concepts from Trevarthen $(1979,1980)$ who widely studied the interaction between infants and their mothers and who defines primary intersubjectivity as 'direct face-to-face play' (1980, p. 327). In their article, Gallagher and Jacobson understand primary intersubjectivity as an immediate engagement with another person without the mediation from, or need of, other objects or people (2012, p. 219). For example, they state that ' $[\mathrm{p}]$ ersonal, face-to-face, emotion-rich relations [are] the kind of relations that depend heavily on primary intersubjectivity' (2012, p. 225). Later in the essay they talk of primary intersubjectivity as essential to relations such as friendship and love (2012, p. 238). Secondary intersubjectivity, according to them, 'supplements' and 'enhances' primary intersubjectivity. Here, through shared attention to the world surrounding us, pragmatic contexts come into play and show us 'what things mean and what they are for' (2012, p. 221). This leads them at the end of their discussion of secondary intersubjectivity to state that 'our perception of the other person is never of an entity existing outside of a situation, but rather of an agent in a pragmatic context that throws light on the intentions, or possible intentions, of that agent' (2012, p. 223).

How does one square such a statement with the existence of an immediate relation in primary intersubjectivity? It is not that primary intersubjectivity is only present in early childhood (as their work in developmental psychology might suggest) for they make a point of stating that it remains present in adulthood (2012, p. 221), nor is it, as the following description of their account of it shows, a mentalistic, disembodied interaction: 'perceptions [of facial and body movements] give the infant, by the end of the first year of life, a non-mentalizing, perceptuallybased embodied understanding of the intentions and dispositions of other persons' (2012, p. 220). In their account, then, primary intersubjectivity is embodied but does not seem take the context, at least thematically, into account. The world only comes in explicitly in secondary intersubjectivity. So, whereas Heidegger's das Man is always already a Da-sein, being-there entangled in meaningful objects and persons meaningfully engaging with these objects, already taking part in the sociohistorical practices of das Man, in Gallagher and Jacobson's account there is a significant difference between primary and secondary intersubjectivity, between direct contact with the other and mediated contact with them. It is from this position that they criticize Heidegger for skipping over the former.

\footnotetext{
${ }^{19}$ There is a third aspect to intersubjectivity that Gallagher names 'narrative competency, but this aspect is not further discussed in their article. For an account of narrative competency please refer to Gallagher and Hutto's 'Primary Interaction and Narrative Practice' (2008).
} 


\section{Unworldly primary intersubjectivity}

In their article Gallagher and Jacobson criticize Heidegger for ignoring primary intersubjectivity, for only paying attention to pragmatic encounters directed toward objects, and therefore for lacking a coherent understanding of immediate, emotionrich, face-to-face relations $(2012$, p. 223-5). They state that '[b]ecause Heidegger's account ignores the phenomenon of primary intersubjectivity, he is left with $[\ldots]$ a view that makes authentic relations with others, including relations of friendship and love, difficult to understand' $(2012$, p. 237-8). They have an abundance of evidence from developmental psychology for the presence of primary intersubjectivity in infants; as they show, infants discover (the body of) others first, and only through them the environment (2012, p. 219-221). ${ }^{20}$ However, as Gallagher and Jacobson point out, Heidegger exactly 'is not attempting to provide anything like a developmental account' $(2012$, p. 227). To a critique of a lack of an account of primary intersubjectivity in Heidegger it is therefore imperative to have an account of primary intersubjectivity beyond the infant. Arguing for the existence of primary intersubjectivity in adults Gallagher and Jacobson quote Wittgenstein and Scheler. The latter states: '[f]or we certainly believe ourselves to be directly acquainted with another person's joy in his laughter, with his sorrow and pain in his tears, with his shame in his blushing [...]' (qtd. in Gallagher and Jacobson 2012, p. 221). However, is it not precisely the case that we need the shared world (in its mutually constitutive relationship with the meaningful gestures of others) to tell us about the feelings behind blushing or tearing up? Let us take the example of a student presenting a paper in an academic setting. If their face were to turn red here, everyone would think them to be nervous, even though they could be hot or have a fever. This does not need any mental reflexion. Why? Because they are a student reading a paper, in front of a big group of people, in an academic institution, and so on. It is part of our shared understanding of the world that in this context one might be nervous. In other words, how can I understand the 'expression' of an emotion without the shared, concrete context toward which it gestures? How can I understand tears, redness, and laughter without this context? $?^{21}$

Yet, Gallagher and Jacobson might argue that context is indeed important but that it is just that: an unthematic context which supports the immediate engagement with the other. Indeed, I think that is exactly what the discussions of the body as Leib, and the gestures of the other person in Heidegger are pointing toward: both the immediacy of our engagement in the world (whether with an object or another person), and the inseparability of the other and objects from their contexts. To be embodied in the world

\footnotetext{
${ }^{20}$ For evidence of the presence of primary intersubjectivity Gallagher and Jacobson cite, among other works, Allison et al. 2000; Johnson 2000; Gopnik and Meltzoff 1997; Baldwin 1993.

${ }^{21}$ It bears mentioning that we are of course more familiar with some people's gestures than we are with others'. Because we have, as mentioned earlier, always already learned to be a body from others (and continue to do so), within a meaningful, socio-cultural environment, we usually understand better the behaviour in a context of close family and partners than of colleagues, and similarly better those gestures of the people within the same culture as of those without. In general, the extent to which gestures and our meaningful environments are shared also depends on our grain of analysis. For more on grains of analysis in the context of human behaviour see Rietveld and Kiverstein 2014, p. 329-330.
} 
in Heidegger means that we take in the whole situation, including its socio-historical background, unmediated and holistically. ${ }^{22}$ To speak in the manner of Heidegger's Dasein, to be in the situation with the student also means to be 'there' in the place of the nervous student. I would argue, therefore, that if there is anything missing in Heidegger's account of being-with and Das Man it is not primary intersubjectivity but rather secondary intersubjectivity if understood as mediated by objects. There is, in Heidegger, no mediation via either my body, objects or other people, but rather one meaningful world, one 'totality of references' (2010, p. 69), with which we, for the largest part, engage immediately. If there is anything like secondary intersubjectivity in Heidegger, in which others are mediated through objects, this secondary intersubjectivity marks a step back from our fundamental embodied existence in the world. ${ }^{23}$

Even so, these arguments take nothing away from Gallagher and Jacobson's concern that it seems that Heidegger is more interested in objects than other people. However, as I will argue in the following section, such a reading of being-with overlooks several paragraphs in which Heidegger concerns himself with our direct engagement to others. But not only does Heidegger indeed pay attention to something akin to the 'face-toface' but he is also concerned about an issue similar to the difference between primary and secondary intersubjectivity: Heidegger emphasizes in our engagement with others the difference between focusing one's (immediate) attention on others and focusing so on objects.

\section{The face-to-face in Heidegger: authentic Fürsorge}

Gallagher and Jacobson's critique of a lack of primary intersubjectivity in Heidegger's concept of being-with also points to the fact that he seems to pay more attention to objects than other people. Other commenters on Heidegger's account of being-with, too, have pointed out that he seems less interested in face-to-face relations than he is in people working with each other in their everyday concerns in the world; Sartre, for example, describes Heidegger's understanding of being-with as a 'crew' [équipe]

\footnotetext{
22 This is also the answer, I believe, to a problem posed by Overgaard in a recent article. He states-via Merleau-Ponty (2012, p. 190) - the following: "the meaning of the gesture is, as Merleau-Ponty says, "not given but rather understood," and that means we still need an account of how we understand it' (2017, p. 77). I would argue that in Heidegger we exactly find such an account, namely in his concept of das Man. Heidegger's answer, I believe, would be that the shared world we live in and the meaningful gestures that point toward it are mutually constitutive.

${ }^{23}$ As an example of such a stepping back from our immediate relation to the other Heidegger talks of empathy [Einfühlung]. An attempt at empathy, Heidegger states, is a consequence of not recognizing that we are already in understanding of each other, are being-with, partly due to the fact that we hide our true feelings toward one another. Instead of our embodied being in the world, therefore, with empathy we consciously start to deliberate what the other might be feeling, and thus, according to Heidegger, we take a step back from the world again: " "[e]mpathy" does not first constitute being-with, but is first possible on its basis, and is motivated by the prevailing deficient modes of being-with in their inevitability' (2010, p. 121). Just as contemplating my arm while hammering takes me away from my involvement in a world disclosing task, such empathy artificially removes us from our being-in-the-world and being-with-others. Such empathy to Heidegger is not only a step away from the fundamental ontology of how we always already are in the world, but it also brings forth a disingenuous stance towards the other we encounter, he writes: "[i]nconsiderate" being-with "reckons" with others without seriously "counting on them" or even wishing "to have anything to do" with them' (2010, p. 122).
} 
(1965, p. 303; see also e.g. Dreyfus 1997, p. 148-9; Zahavi 2001). However, such a description of being-with also leaves much of Heidegger's discussion of it in Being and Time underexamined. This problem is largely caused by Heidegger himself; the fact that he starts, as we have seen, his analysis with objects instead of people certainly invites a reading which stresses objects. Nevertheless, Heidegger seems repeatedly worried about the ways in which, and the extent to which, we pay attention to others 'face-to-face'. He, for example, discusses 'deficient and indifferent modes up to the point of inconsiderateness and the tolerance which is guided by indifference' (2010, p. 119). This attention to the other is most clear in his discussion of Fürsorge, which Stambaugh translates as 'concern' (2010, p. 118). Fürsorge is the way in which we engage with others, which stands in contrast to the way in which we 'take care of' [besorgen] objects. Fürsorge is concerned with the other person as a Dasein, as a being meaningfully engaged in the world; Heidegger opens his discussion of it with the statement that provision of 'food and clothing, and the nursing of the sick body is concern [Fürsorge]' (2010, p. 118, German added). But to emphasize that our concern for others is often deficient, he immediately thereafter references the common meaning of 'Fürsorge' in German, namely that as social welfare, a system he deems necessary only because of our deficient everyday caring for others (2010, p. 118). Heidegger's treatment of Fürsorge thus shows that being-with for him is more than a working together with others as a crew to get things done, or a relation that focuses in the first place on objects; we are engaged with the needs of others too. Indeed, he continues with discussing the degree of our openness to others (in 'considerateness' [Rücksicht] and 'tolerance' [Nachsicht]). And, most importantly for our present discussion, he makes a difference between authentic and inauthentic Fürsorge, and through this a significant difference between whether we pay attention to objects, or other people in their meaningful engagement with the world. On the one hand, we can 'leap in' [einspringen] for others, by which we take care of the things the other is meant to take care of for themselves. The other, then, becomes 'displaced' and 'can become someone who is dependent and dominated' (2010, p.118-9). This is, according to Heidegger, what happens when we focus our attention on the object that the other is taking care of instead of focusing on the other herself in her meaningful engagement in the world, as authentic Fürsorge does. About 'leaping ahead' [vorspringen], namely, Heidegger states: 'this concern which essentially pertains to authentic care - that is, it pertains to the existence of the other, and not to a what which it [the other] takes care of-helps the other to become transparent to himself in his care and free for it' (2010, p. 119, brackets added). ${ }^{24}$ With this distinction between the inauthentic leaping in and the authentic leaping ahead of concern, then, which has something of the old proverbial 'give a man a fish and feed him for a day; teach a man to fish and you feed him for a lifetime', we find exactly what Gallagher and Jacobson are looking for in Heidegger: an account of an immediate and meaningful engagement with the other. Even if this relationship still has something crew-like about it, and is certainly still pragmatic-Heidegger later describes this authentic relation in terms of 'devot[ing] themselves to the same thing

\footnotetext{
${ }^{24}$ For more on 'leaping ahead', especially in relation to authenticity in division II of Being and Time see $\$ 60$, in particular page 285. 'Leaping ahead' [vorspringen] seems here, too, to be linked to 'anticipation' [vorlaufen] as the possibility of helping others to become authentic.
} 
in common' (2010, p. 119) — it is certainly a crew of people engaged with the others as who they are: meaningfully acting people.

\section{A pragmatic encounter with the other}

Even if there is an account of the face-to-face in Heidegger, there still may be a fear that an immediate, pragmatic approach to the other person, especially in their own pragmatic engagements, may lead to a treatment of them as an object, to a lack of consideration for their feelings. This reservation is certainly found in Gallagher and Jacobson:

[I]n an analysis of intersubjectivity which is made exclusively in terms of secondary intersubjectivity, and for Heidegger, that means in terms of the ready-to-hand contexts within which we find others, there is a certain kind of interchangeableness amongst others. The everyday public world is often characterized by Heidegger as a workplace filled with equipment, or as a world of commodities, where others are encountered in terms of their particular functions.

(2012, p. 225)

But why do people become interchangeable if we encounter them in their pragmatic encounters with useful objects? Do I not prefer one kind of shoe over another and therefore one shoemaker over another? Heidegger certainly makes sure to imply as much when he first talks about encountering others through the shared world: 'the producer or "supplier" is encountered in the material used as one who "serves" well or badly' (2010, p. 115, emphasis mine). It is important to recognize that we not only discover the other person through the objects we engage with, but that we also discover their view of the world in this way. ${ }^{25}$ Through a shoe we not only understand why a shoemaker is useful but also how he thinks a shoe should be made. Indeed, that we also find other people's hopes and dreams in the objects we uncover is what Heidegger implies in the quote that started this article: '[Dasein] finds itself primarily and constantly in things because, tending them, distressed by them, it always in some way or other rests in things' (1988, p. 159). Thus, we do not discover only the usefulness of another Dasein in the object, but also the way in which they regard the world, how they are occupied by it. In such an understanding of the objects we deal with, we also start to make distinctions between different people, distinctions that can very well lead to friendships and love. ${ }^{26}$ Surely, we choose our friends and lovers for

\footnotetext{
${ }^{25}$ Gallagher and Jacobson also criticize Heidegger for a secondary intersubjectivity 'that is just opposite to the way it is described by developmental psychologists' (227). In Heidegger, they state, we establish relations to objects and through them with other people, while for developmental psychology we rather give meaning to objects through others. However, this is again to not recognize that Heidegger is not interested in the process of the construction of meaning but rather in pointing out that the world we live in is already full of meaning that we encounter through objects (and people engaging with these objects) on a daily basis. See also Olafson (1987), p. 146ff for a similar critique to that of Gallagher and Jacobson, and Dreyfus (1997), p. 142ff for an extensive reply to this critique.

${ }^{26}$ While Gallagher and Jacobson acknowledge the possibility of distinguishing between people in terms of the quality of what they do, they dismiss this possibility as an account toward love or friendship as soon as it arises (2012, p. 225).
} 
many different reasons but many of them have to do with how they deal with objects. We like our friends because they react to objects in a certain way and because they like certain objects and dislike others. We like our friends because they like the same TV shows as us and we might like our lovers because they fidget constantly with their clothing. I have already tried to show that there is no lack of primary intersubjectivity in Heidegger if it means an immediate engagement with the other, nor does he lack an account of the face-to-face, but neither does his pragmatic approach, I believe, take away from such things as love and friendship, it just makes these relationships less abstract and more engaged. Of course, it is significant to human relationships how the other thinks and feels, but all this is a thinking and feeling about the world, in meaningful situations. This view of love and friendship may seem pragmatic, and it is, but that is exactly why we can never reason our way into love. A step back from this pragmatism, however, is only a denying of a relation we are always already in.

\section{Conclusion}

Gallagher and Jacobson raise important questions about Heidegger's attention to faceto-face encounters. He certainly seems more interested in how people ride a bus together than in these people having meaningful conversations. It is at least peculiar that he starts his discussion of being-with with the observation that we encounter the farmer through the field we walk past. Nevertheless, his account of das Man shows that he certainly believes that we do not only encounter others in objects but also that others are central to how we understand objects. Moreover, his discussion of Fürsorge opens up a space in Heidegger's Being and Time beyond an analysis of being-with as merely a crew of people acting together, toward the immediate face-to-face relations Gallagher and Jacobson are looking for. In authentic Fürsorge we do not engage with the objects of the other person's engagement but, in line with how Heidegger describes our understanding of the other's physical movement in the Zollikon Seminars as gesture, we engage exactly with the other person as engaging meaningfully with our shared world, as always already 'tied into' a meaningful context. If there is anything missing from Heidegger fundamental ontology of the other, then, it is not the immediate, 'faceto-face' relation of primary intersubjectivity but rather a secondary intersubjectivity, the mediation of our relation to the other through objects.

Gallagher and Jacobson's critique of Heidegger's lack of an account of primary intersubjectivity shares, therefore, the same assumption that drove the critiques of Merleau-Ponty and Sartre: that the lack of a discussion of the body as a Körper, rather than being an indication of a more radical position on embodiment, means that embodiment is insufficiently acknowledged in Heidegger's account of being-in-theworld. An attention to Heidegger's understanding of the body as Leib, as laid out in the Zollikon Seminars, reveals the extent to which Dasein is always already immersed in its world. In Heidegger's view, embodied practice goes beyond the situated subject into the world: it is always already also elsewhere. When I am sitting here I am with the birds that I hear outside, with the table that I feel in front of me, and with the audience that I am addressing. Far from being self-contained, I am 'there,' and in so being I am also always already involved in the socio-historical framework constituted by these objects and people, or what Heidegger calls das Man. In such a view of 
intersubjectivity, the other Dasein is always already engaged with immediately and in a meaningful context. The model of ecstatic involvement we can take away from Heidegger, then, is one of immediacy where the division between primary and secondary intersubjectivity that underlies much research on intersubjectivity in the cognitive sciences since Trevarthen is replaced with the (ethically important) distinction between paying attention to objects and paying attention to other people. This model opens up a space for thinking about intersubjectivity away from mediation toward a holistic picture, different parts of which we focus on in our embodied involvement. We might focus on objects but they are still shaped and made meaningful by others, and we may focus on others but they equally are shaped by a shared environment. An understanding of the extent of Dasein's immersion in the world is, thus, essential to any Heideggerian approach to the cognitive sciences. Moreover, such an account of embodiment in Heidegger shows the importance of environments in human interaction. Recent research (e.g. Kiverstein 2015) which emphasizes the place of the environment in human interaction is therefore an important step forward in understanding the way in which human encounters, even the most intimate ones, are shaped.

The anxiety caused by Heidegger's radical stance on embodiment stems from the assumption that defining human relationships in terms of practicality results in our relationships becoming impersonal and interchangeable. How do we account for love and friendship when usefulness is understood as the primary way of relating to people? A pragmatic relationship with another person, however, does not mean that they become interchangeable. As argued, to see someone as the maker of my shoe, does not mean I cannot prefer him as a shoemaker over all the others. Love and friendship, indeed, may be more grounded in physical 'in-the-world' relations than we would like to think. The way we watch a Disney movie together may just be a more fundamental relation than staring into each other's eyes. But even if this is so, Heidegger never states that we cannot take a mental step back from our pragmatic being-in-the-world, from our Dasein, but such a position just may obscure more than it reveals.

Acknowledgements I would like to thank Ben Morgan for lending me his critical eye and for his many comments and suggestions. I would also like to thank Alexandra Whelan and Kevin Brazil as well as the peer reviewers for their many excellent comments and suggestions on this article.

Open Access This article is distributed under the terms of the Creative Commons Attribution 4.0 International License (http://creativecommons.org/licenses/by/4.0/), which permits unrestricted use, distribution, and reproduction in any medium, provided you give appropriate credit to the original author(s) and the source, provide a link to the Creative Commons license, and indicate if changes were made.

\section{References}

Aho, K. A. (2009). Heidegger's neglect of the body. Albany: State University of New York Press.

Allison, T., Puce, A., \& McCarthy, G. (2000). Social perception from visual cues: Role of the STS region. Trends in Cognitive Sciences, 4(7), 267-278.

Baldwin, D. A. (1993). Infants' ability to consult the speaker for clues to word reference. Journal of Child Language, 20(2), 395-418.

Bateson, M. C. (1975). Mother-Infant Exchanges: The Epigenesis of Conversational Interaction. In D. Aaronson \& R. W. Rieber (Eds.), Developmental Psycholinguistics and Communication Disorders 
(Annal of the New York Academy of Sciences) (pp. 101-113). New York: New York Academy of Sciences.

Butterworth, G. (2004). Joint visual attention in infancy. In J. Gavin Bremner \& A. Slater (Eds.), Theories of infant development (pp. 317-354). Malden: Blackwell Publishing.

Carman, T. (1994). On being social: A reply to Olafson. Inquiry, 37(2), 203-223.

Cerbone, D. R. (2000). Heidegger and Dasein's 'bodily nature': What is the hidden problematic? International Journal of Philosophical Studies, 8(2), 209-230.

Colombetti, G. (2014). The feeling body: Affective science meets the enactive mind. Cambridge: The MIT Press.

De Jaegher, H., \& Di Paolo, E. (2007). Participatory Sense-making: An Enective Approach to Social Cognition. Phenomenology and the Cognitive Sciences, 6(4), 485-507.

De Waelhens, A. (1965). Philosophy of the ambiguous. Introduction to The Structure of Behaviour, by Maurice Merleau-Ponty, xviii-xxvii. Translated by Alden L. Fisher. London: Methuen.

Dreyfus, H. L. (1995). Interpreting Heidegger on Das Man. Inquiry, 38(4), 423-430.

Dreyfus, H. L. (1997). Being-in-the-world: A commentary on Heidegger's being and time, division I. Cambridge: The MIT Press.

Franck, D. (1991). Being and the Living. In E. Cadava, P. Connor, \& J.-L. Nancy (Eds.), Who Comes After the Subject? (pp. 135-147). London: Routledge.

Gallagher, S. (2001). The practice of mind: Theory, simulation or primary interaction? Journal of Consciousness Studies, 8(5-7), 83-108.

Gallagher, S. (2004). Understanding interpersonal problems in autism: Interaction theory as an alternative to theory of mind. Philosophy, Psychiatry, and Psychology, 11(3), 199-217.

Gallagher, S. (2005). How the body shapes the mind. Oxford: Clarendon Press.

Gallagher, S. (2008). Inference or interaction: Social cognition without precursors. Philosophical Explorations, 11(3), 163-173.

Gallagher, S., \& Hutto, D. D. (2008). Primary Interaction and Narrative Practice. In J. Zlatev, T. P. Racine, C. Sinha, \& E. Itkonen (Eds.), The Shared Mind: Perspectives on Intersubjectivity (pp. 17-38). Amsterdam: John Benjamins.

Gallagher, S., \& Jacobson, R. S. (2012). Heidegger and social cognition. In J. Kiverstein \& M. Wheeler (Eds.), Heidegger and cognitive science (pp. 213-245). New York: Palgrave Macmillan.

Gallagher, S., \& Zahavi, D. (2008). The phenomenological mind. London: Routledge.

Gopnik, A., \& Meltzoff, A. N. (1997). Words, thoughts, and theories. Cambridge: MIT Press.

Heidegger, M. (1987). Zollikoner Seminare: Protokolle-Gespräche-Briefe. Vittorio Klostermann: Frankfurt am Main.

Heidegger, M. (1988). The Basic Problems of Phenomenology. Translated by Albert Hofstadter. Revised Edition. Bloomington: Indiana UP.

Heidegger, M. (2001). Zollikon seminars: Protocols - Conversations -letters. Edited by Medard Boss. Translated by Franz Mayr and Richard Askay. Evanston: Northwestern UP.

Heidegger, M. (2010). Being and Time. Translated by Joan Stambaugh. Albany: State University of New York Press.

Johnson, S. C. (2000). The recognition of Mentalistic agents in infancy. Trends in Cognitive Sciences, 4(1), $22-28$.

Kiverstein, J. (2015). Empathy and the responsiveness to social affordances. Consciousness and Cognition, $36,532-542$.

Krell, D. F. (1992). Daimon Life: Heidegger and Life-Philosophy. Bloomington: Indiana UP.

Legerstee, M. (1991). The role of person and object in eliciting early imitation. Journal of Experimental Child Psychology, 51, 423-433.

Levin, D. M. (1999). The ontological dimension of embodiment: Heidegger's thinking of being. In D. Welton (Ed.), The body: Classic and contemporary readings (pp. 122-149). Oxford: Blackwell.

Meltzoff, A.N. and Brooks R. (2001). 'Like me' as a building block for understanding other minds: Bodily acts, attention, and intention. In Bertram F. Malle, et al. (Eds.), Intentions and Intentionality: Foundations of Social Cognition (pp. 171-191).

Meltzoff, A. N., \& Moore, M. K. (1977). Imitation of facial and manual gestures by human neonates. Science, 198, 75-78.

Merleau-Ponty, M. (1965). The Structure of Behaviour. Translated by Alden L. Fisher. London: Methuen.

Merleau-Ponty, M. (2012). Phenomenology of Perception. Translated by Donald. A. Landes. London: Routledge.

Olafson, F. (1987). Heidegger and the Philosophy of Mind. New Haven: Yale UP.

Olafson, F. (1994). Heidegger à la Wittgenstein or 'coping' with professor Dreyfus. Inquiry, 37(1), 45-64. 
Overgaard, S. (2004). Heidegger on Embodiment. Journal of the British Society for Phenomenology, 35(2), 116-131.

Overgaard, S. (2017). Other minds embodied. Continental Philosophy Review, 50(1), 65-80.

Ratcliffe, M. (2007). Rethinking commonsense psychology: A Critique of Folk Psychology, Theory of Mind and Simulation. Basingstoke: Palgrave MacMillan.

Rietveld, E., \& Kiverstein, J. (2014). A rich landscape of affordances. Ecological Psychology, 26(4), 325-352.

Sartre, J.-P. (1965). L'être et le néant: Essai d'ontologie phénoménologique. Paris: Gallimard.

Sartre, J-P. (1989). Being and Nothingness: An Essay on Phenomenological Ontology. Translated by Hazel E. Barnes. London: Methuen.

The Little Mermaid. (2013). Dir. Ron Clements and John Musker. Walt Disney home entertainment.

Tiemersma, D. (1989). Body Schema and body image: An interdisciplinary and philosophical study. Amsterdam: Swets \& Zeitlinger.

Trevarthen, C. (1979). Communication and Cooperation in Early Infancy: A Description of Primary Intersubjectivity. In M. Bullowa (Ed.), Before Speech: The Beginning of Interpersonal Communication. Cambridge: UP.

Trevarthen, C. (1980). The foundations of Intersubjectivity: Development of interpersonal and cooperative understanding of infants. In D. R. Olsen (Ed.), The social Foundation of Language and Thought: Essays in honor of Jerome S. Bruner (pp. 316-341). New York: Norton.

Wheeler, M. (2005). Reconstructing the cognitive world: The next step. Cambridge: The MIT Press.

Zahavi, D. (2001). Beyond empathy. Phenomenological Approaches to Intersubjectivity. Journal of Consciousness Studies, 8(5-7), 151-167. 